\title{
TP53 NP_000537.3:p.R282G
}

National Cancer Institute

\section{Source}

National Cancer Institute. IP53 NP 000537.3:p.R282G. NCI Thesaurus. Code C146925.

A change in the amino acid residue at position 282 in the cellular tumor antigen p53

protein where arginine has been replaced by glycine. 